\title{
ATTENUATION OF SOUND IN SEA ICE, Io-500 kHz
}

\author{
By M. P. Langleben \\ (Ice Research Project, Department of Physics, McGill University, Montreal, Quebec, Canada)
}

\begin{abstract}
Measurements of the attenuation of acoustic waves in sea ice at frequencies $f$ between $10 \mathrm{kHz}$ and $500 \mathrm{kHz}$ have been made on the ice cover at Tanquary Fiord, Ellesmere Island (lat. $81^{\circ} 25^{\prime} \mathrm{N}$., long $76^{\circ} 5^{\circ}$ W.). A horizontal transmission path at a depth of $4 \mathrm{ft}(\mathrm{I} .3 \mathrm{~m})$, mid-way between the top and bottom surfaces of the ice cover, was used at ranges varying from $25 \mathrm{ft}(7.6 \mathrm{~m})$ to $4 \mathrm{ft}(\mathrm{r} .3 \mathrm{~m})$ between piezoelectric transducers immersed in oil-filled bore holes. The attenuation coefficient $\alpha$ was found to fit the equation $\alpha=c_{1} f+c_{2} f^{4}$ with $c_{1}=4.45 \times 10^{-2} \mathrm{db} \mathrm{m}^{-1} \mathrm{kHz}^{-1}$, and $c_{2}=2.18 \times \mathrm{IO}^{-10} \mathrm{db} \mathrm{m}^{-1} \mathrm{kHz}^{-4}$. Over the frequency band covered, the linear term was predominant and the Rayleigh scattering term relatively insignificant.

RÉsumé. L'atténuation du son dans la glace de la mer, $10-500 \mathrm{kHz}$. Nous avons mesuré l'atténuation des ondes acoustiques dans la glace de mer, à des fréquences $f$ se situant entre ro $\mathrm{kHz}$ et $500 \mathrm{kHz}$, sur la couche de glace à Tanquary Fiord, Ellesmere Island $\left(81^{\circ} 25^{\prime} \mathrm{N}, 76^{\circ} 50^{\prime} \mathrm{W}\right)$. Un guide horizontal de propagation à une profondeur de $1,3 \mathrm{~m}$, à mi-chemin entre le dessus et la dessous de la glace, fut utilisé à une distance variant de $7,6 \mathrm{~m}$ à $\mathrm{I}, 3 \mathrm{~m}$, entre des organes de transmission piezoélectriques plongées dans des trous remplis d'huile. Nous avons trouvé que le coefficient d'atténuation $\alpha$ satisfait l'équation $\alpha=c_{1} f+c_{2} f^{4}$ avec $c_{1}=4,45 \times 10^{-2} \mathrm{db} \mathrm{m}^{-1} \mathrm{kHz}^{-1}$ et $c_{2}=2,18 \times 10^{-10} \mathrm{db} \mathrm{m}^{-1} \mathrm{kHz}^{-4}$. Dans la bande de fréquence étudiée, le terme linéaire était prédominant et le terme de diffusion de Rayleigh était relativement minime.
\end{abstract}

Zusammenfassung. Schalldämpfung im Meereis, $10-500 \mathrm{kHz}$. Messungen der Dämpfung von akustischen Wellen mit Frequenzen $f$ zwischen $10 \mathrm{kHz}$ und $500 \mathrm{kHz}$ in Meereis wurden auf der Eisdecke des Tanquary Fiord, Ellesmere Island (Breite $81^{\circ} 25^{\prime} \mathrm{N}$, Länge $76^{\circ} 50^{\prime} \mathrm{W}$ ), vorgenommen. Eine horizontale Laufstrecke in einer Tiefe von $4 \mathrm{ft}(1,3 \mathrm{~m})$, in der Mitte zwischen Ober- und Unterseite der Eisdecke, wurde benutzt; die Strecken zwischen den piezoelektrischen Ultraschallerzeugern, die in oelgefüllte Bohrlöcher eingetaucht waren, varïerten zwischen $7,6 \mathrm{~m}$ und $\mathrm{I}, 3 \mathrm{~m}$. Für den Dämpfungskoeffizient $\alpha$ ergab sich die Gleichung $\alpha=c_{1} f+c_{2} f^{4}$ mit $c_{1} \times 4,45 \times 10^{-2} \mathrm{db} \mathrm{m}^{-1} \mathrm{kHz}^{-1}$ und $c_{2}=2,18 \times \mathrm{IO}^{-10} \mathrm{db} \mathrm{m}^{-1} \mathrm{k} \mathrm{Hz}^{-4}$. Im benutzten Frequenzband dominierte das lineare Glied, während das Glied der Rayleigh'schen Zerstreuung relativ insignifikant blieb.

\section{INTRODUCTION}

The propagation in sea ice of acoustic waves and pulses has been used extensively to investigate the elastic properties of that material (e.g. Anderson, 1958; Pounder and Langleben, 1964). In these studies it has sometimes been noted that the high-frequency components tend to suffer greater attenuation than the low-frequency components, but no quantitative data on attenuation in sea ice are available. There have been numerous investigations however of acoustic attenuation in other polycrystalline substances such as metals and rocks (e.g. Mason and McSkimin, 1947; Knopoff and MacDonald, r958) and one on freshwater ice (Westphal, i 965 ). The latter has measured the attenuation coefficient of glacier ice over a frequency range of $2.5 \mathrm{kHz}$ to $\mathrm{I}_{5} \mathrm{kHz}$ by spectral analysis of the pressure pulses from small explosions of seismic blasting caps. In polycrystalline materials, it has generally been found that the attenuation can be related to scattering at the grain boundaries and to internal friction between the grains.

This paper reports on a series of detailed in situ attenuation measurements which were made on the natural cover of sea ice in Tanquary Fiord, Ellesmere Island during the spring of I 967 near the Defence Research Board base camp at lat. $81^{\circ} 25^{\prime}$ N., long. $76^{\circ} 50^{\prime} \mathrm{W}$. Observations were made over a frequency band extending from $10 \mathrm{kHz}$ to $500 \mathrm{kHz}$ using CW transmission along a horizontal path. These investigations had been started in $1_{96} 6_{5}$ and a preliminary account of some results of the field work and of associated laboratory experiments has appeared in Pounder and Langleben (r 968$)$.

\section{Experimental Methods}

The ice cover in Tanquary Fiord was about $8 \mathrm{ft}(2.5 \mathrm{~m})$ thick. Acoustic measurements were made over a horizontal transmission path starting at an extreme range of $25 \mathrm{ft}(7.6 \mathrm{~m})$ to a minimum range of $4 \mathrm{ft}(\mathrm{r} .3 \mathrm{~m})$. Vertical cylindrical holes were drilled in the ice cover 
to a depth of $5 \mathrm{ft}(\mathrm{I} .5 \mathrm{~m})$ to house the sound source and the detector, and were filled with kerosene to provide good acoustic coupling to the ice. After completion of a set of measurements, a new hole was bored for the detector at a lesser range from the sound source and the procedure was repeated.

The acoustic transducers were piezoelectric barium titanate crystals in ceramic discs of thickness $\frac{1}{4}$ in $(6 \mathrm{~mm})$ with a natural frequency of about $45^{\circ} \mathrm{kHz}$ in thickness expansion. Discs of $\mathrm{I}, 4$ and 6 in $\left(2.5\right.$, ro and $\left.\mathrm{I}_{5} \mathrm{~cm}\right)$ diameter served in turn as transmitting transducers and a disc of $\frac{1}{2}$ in $(1.3 \mathrm{~cm})$ diameter was used as receiving transducer. Each transducer was encased to provide water proofing and adequate electric shielding, and in the process the resonant frequency was reduced by about a factor two.

For use, each transducer was mounted at the end of a long pole $\frac{3}{4}$ in $(1.9 \mathrm{~cm})$ in diameter, with its axis perpendicular to the length of the pole. The transducers were then immersed to a depth of $4 \mathrm{ft}$ ( $1.3 \mathrm{~m})$, i.e. mid-way between the top and bottom of the ice cover, to minimize any possible boundary effects on the measurements. Optical alignment of receiving and transmitting transducers was achieved by adjustment of vertical height and orientation fiducial markers on the poles.

The measuring system may be described as follows. The sound source was driven, in CW excitation, by a Hewlett Packard (HP) $6_{5} \mathrm{IA}$ oscillator through an $\mathrm{HP}_{4} 67 \mathrm{~A}$ power amplifier. This oscillator was swept in frequency by an $\mathrm{HP}_{297} \mathrm{~A}$ mechanical sweep drive which also generated an electrical output for the $X$-axis deflection on an $\mathrm{HP}_{135} \mathrm{C} X-Y$ recorder. The receiving system consisted of an $\mathrm{HP}_{4} 00 \mathrm{E}$ voltmeter, used as a pre-amplifier, $\mathrm{HP}_{4} 66 \mathrm{~A}$ and $45^{\circ} \mathrm{A}$ amplifiers in cascade and a diode detector leading to the $Y$-axis input of the recorder. The gain of the system was variable over a wide dynamic range with calibrated attenuators.

In operation, the oscillator was set to sweep the desired frequency band and a graph of received signal as a function of frequency was automatically traced out on graph paper by the $X-Y$ recorder. The procedure was repeated for each reduction in transmitter-receiver range. Care was taken to ensure that the transmitter was driven at constant voltage. In this way, no absolute power measurements were necessary to determine changes in received power or intensity level with changes in length of transmission path.

\section{Observations and Results}

Observations of the ice cover in the vicinity of the operating site indicated that it consisted of two-year-old ice of thickness about $8 \mathrm{ft}(2.5 \mathrm{~m})$. Its salinity along the transmission path was about $0.1 \%$ by weight and its temperature at the same depth about $-6^{\circ} \mathrm{C}$. Horizontal and vertical thin sections revealed the typical structure of sea ice, crystals long in the growth direction perpendicular to the surface and of horizontal dimensions varying from about $\mathrm{I} \mathrm{cm}$ to greater than $5 \mathrm{~cm}$. The typical crystal size in the horizontal was about $2 \mathrm{~cm}$.

Measurements of relative signal intensity level were made at receiver-transmitter ranges

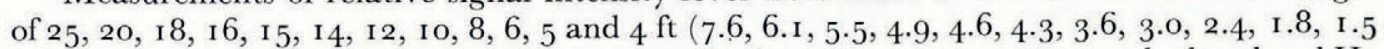
and $1.3 \mathrm{~m}$ ) in the order given. At each range, the frequency was swept over the band $10 \mathrm{kHz}$ to $500 \mathrm{kHz}$. Three such series of measurements were performed using in turn as transmitter, the $\mathrm{I}$ in $(2.5 \mathrm{~cm}), 4$ in $(10 \mathrm{~cm})$ and 6 in $(15 \mathrm{~cm})$ transducers. Detectable signal was obtained over a considerable band of frequency at all of the twelve ranges used, particularly with the two larger transducers (Figures I, 2 and 3 ). At high frequencies where the attenuation was severe, signal merged with background noise at the more distant ranges. At low frequencies, far removed from the resonant frequency of the encased transmitting transducers, the acoustic power output was low and once again the signal could not be distinguished from noise at the more distant ranges used.

The data analysis for each series of measurements was handled in the following manner. Values of recorded signal intensity level were read off the graphs at the grid points of the 

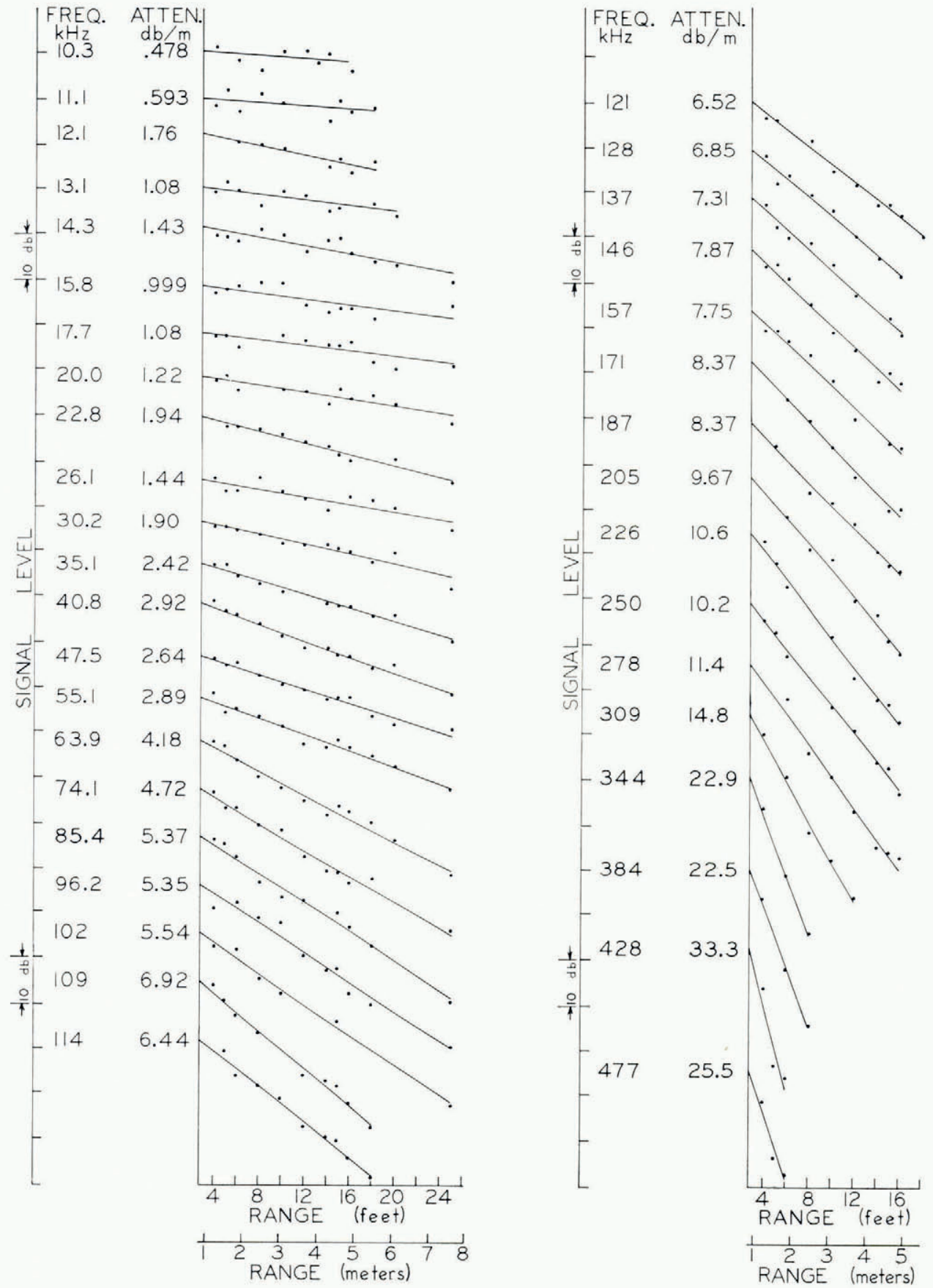

Fig. I. Transmitter of diameter 6 in $(15 \mathrm{~cm})$. Signal intensity level as a function of range at frequencies between $10 \mathrm{kHz}$ and $500 \mathrm{kHz}$. Values of the attenuation coefficient, listed in the ATTEN. column, are the negative of the slopes of the straight lines. 

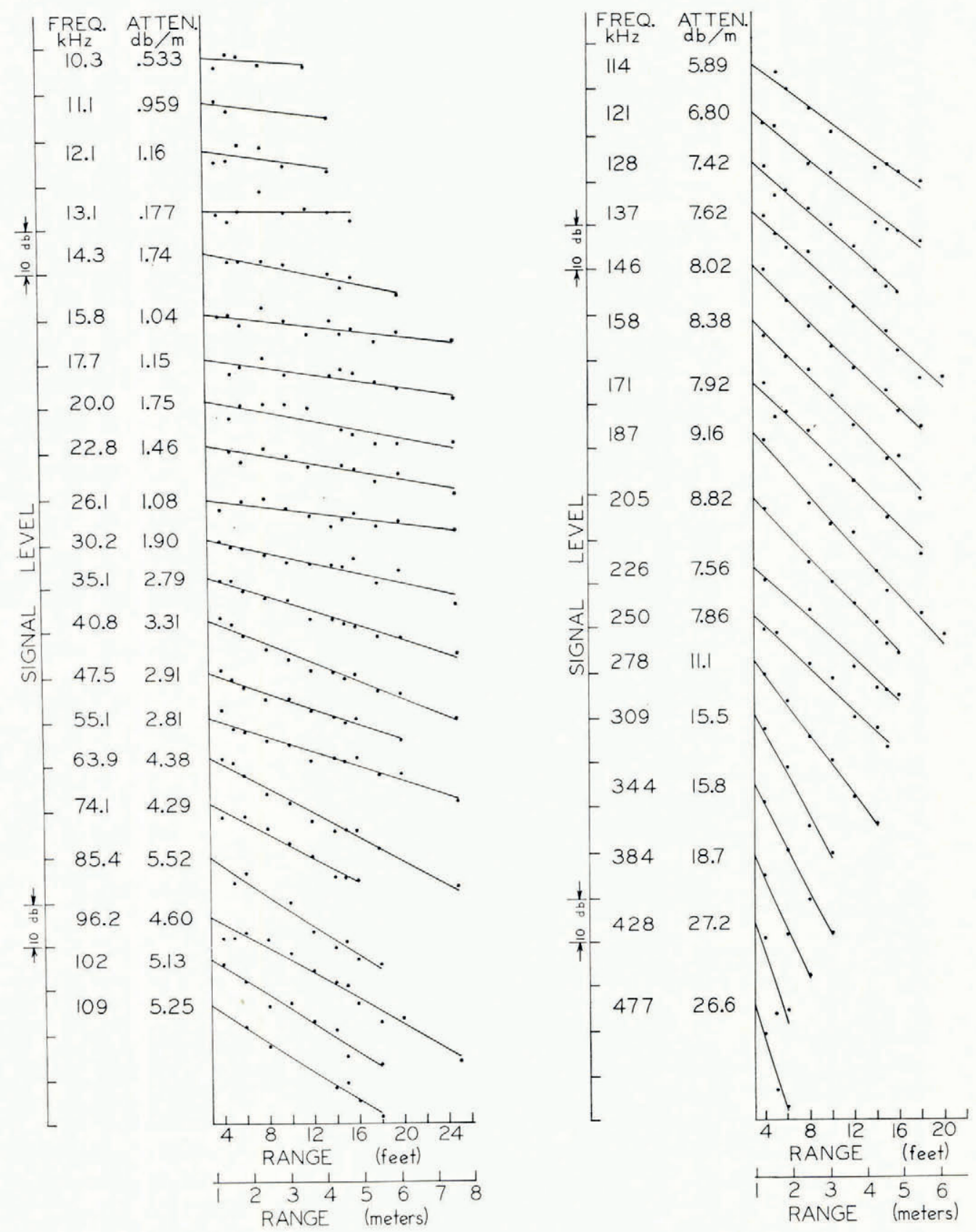

Fig. 2. Transmitter of diameter 4 in $(10 \mathrm{~cm})$. Signal intensity level as a function of range at frequencies between $\mathrm{IO} \mathrm{kHz}$ and 5 oo $\mathrm{kHz}$. Values of the attenuation coefficient, listed in the ATTEN. column, are the negative of the slopes of the straight lines. 

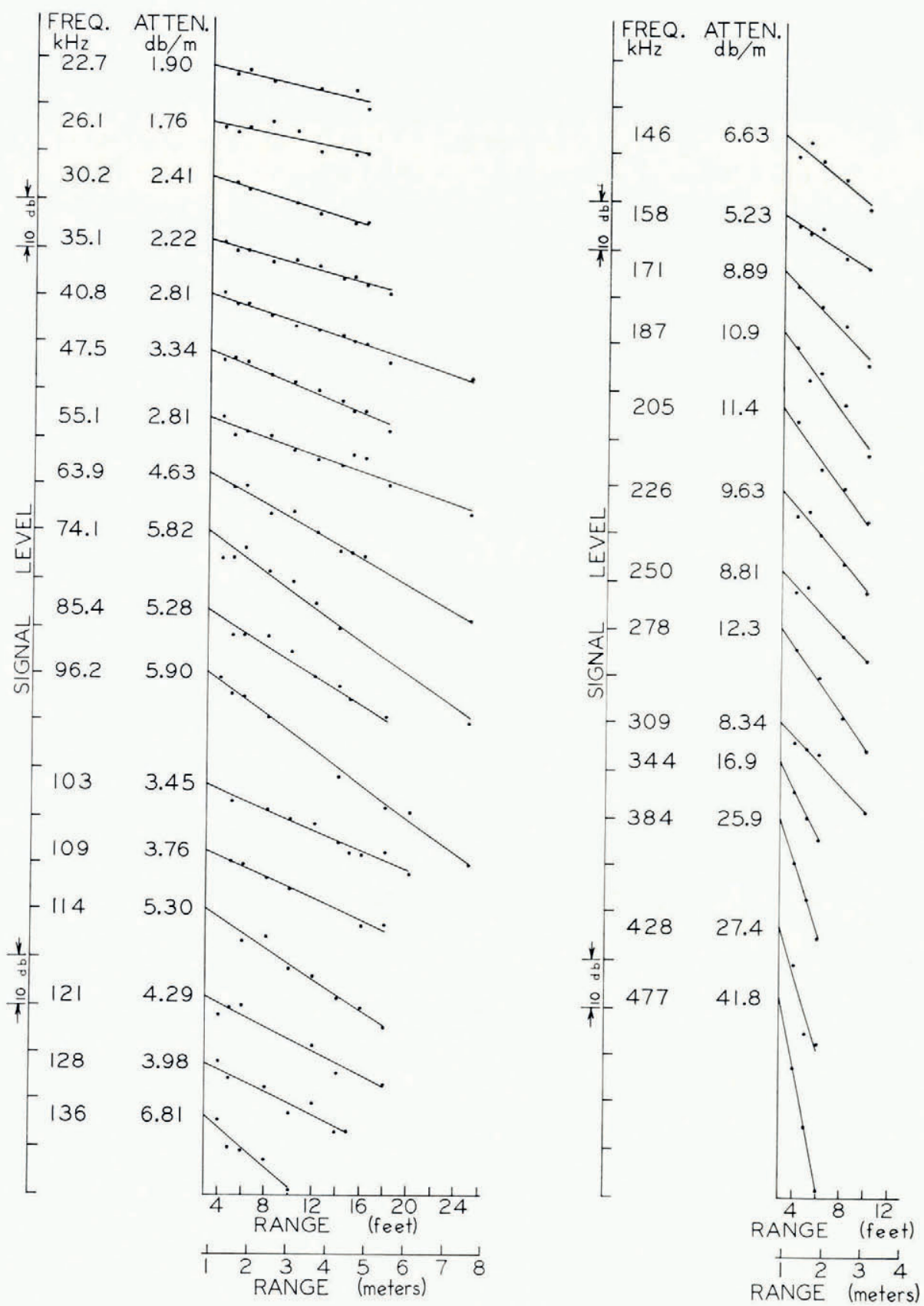

Fig. 3. Transmitter of diameter I in $(2.5 \mathrm{~cm})$. Signal intensity level as a function of range at frequencies between $\mathrm{IO} \mathrm{kHz}$ and $500 \mathrm{kHz}$. Values of the attenuation coefficient, listed in the ATTEN. column, are the negative of the slopes of the straight lines. 
frequency axis (Io points per inch) and were then put on punch cards. Computer data processing averaged the signal intensity level within frequency increments $(38$ increments for the frequency band covered) and prepared in tabular form values of signal intensity level under column headings of transmission range and row headings of frequency. It should be pointed out that, as part of the computer program, these signal levels had been range corrected to allow for beam spread of the transmitter. The directionality characteristics of the transducers when immersed in the oil-filled cylindrical holes in the ice cover had been investigated and it was found that they behaved essentially as point sources in these conditions.

In the next step of the analysis, signal intensity level was plotted as a function of range for each of the frequency increments in turn, producing $3^{8}$ graphs. The straight line of best fit and its slope was computer calculated for each graph using the method of least-squares. These

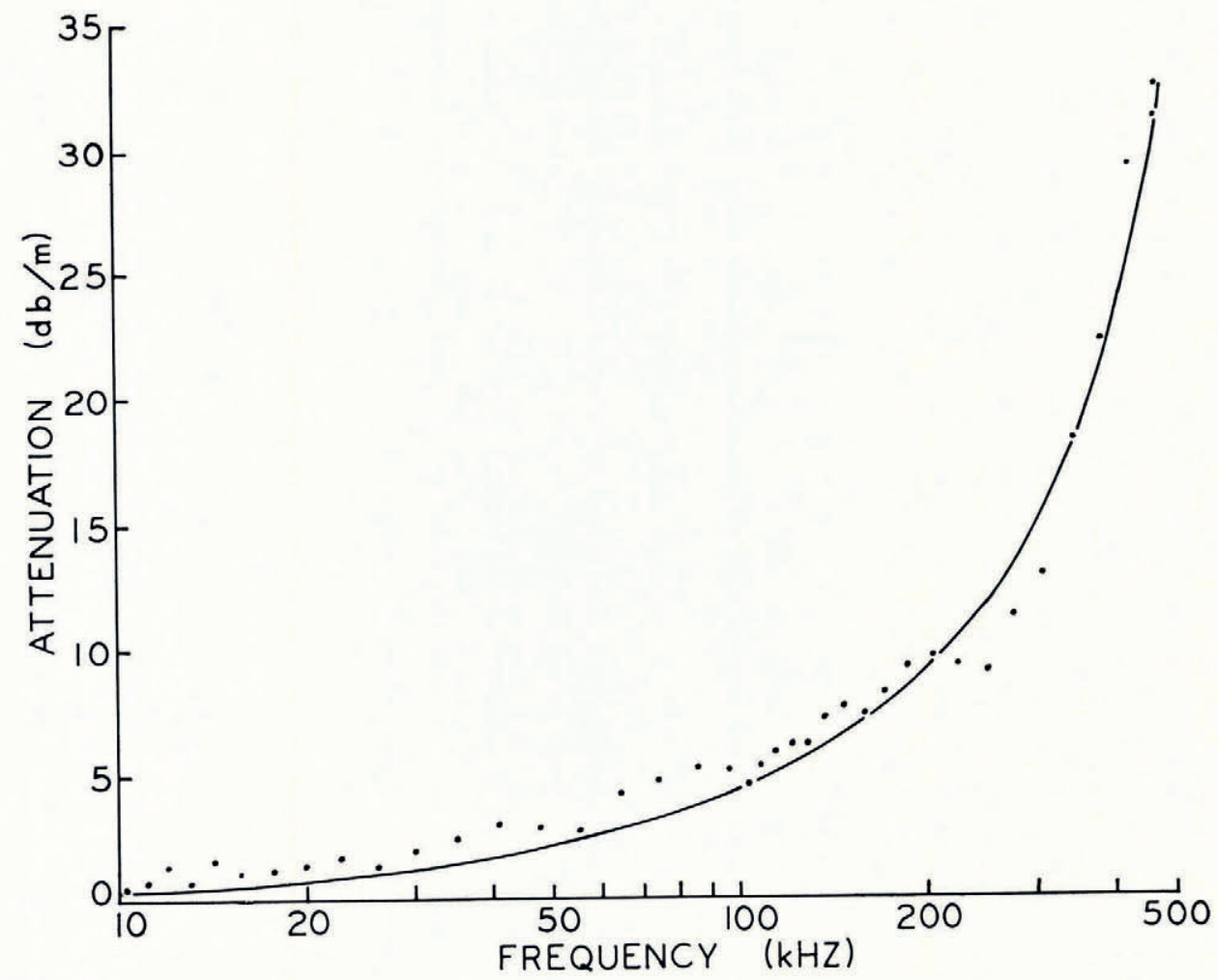

Fig. 4. Attenuation coefficient as a function of frequency.

slopes should have established values of the attenuation coefficient and its variation with frequency. However, some of the data points on the graphs were obviously spurious, a not uncommon occurrence in acoustical measurements. Points which deviated most from the line of best fit were removed one by one, recalculating a new line of best fit each time, until the scatter was limited to within $3 \mathrm{db}$.

The final results of this procedure are shown in Figures I, 2 and 3 for the three series of measurements with transmitting transducers of respectively 6,4 and I in (I 5, Io and $2.5 \mathrm{~cm}$ ) diameter. In each diagram, the ordinate is received signal as intensity level in decibels and the abscissa is the length of the transmission path or range in feet. The series of graphs display the measured points and the lines of best fit at the various frequencies. The two columns beside the graphs list the relevant frequencies in order of increasing magnitude and the corresponding 
attenuation coefficients in $\mathrm{db} \mathrm{m}^{-1}\left(\mathrm{I} \mathrm{db} \mathrm{m}^{-1}=0 . \mathrm{II}_{5}\right.$ nepers $\left.\mathrm{m}^{-1}\right)$ which are equal to the negative of the slope of the lines of best fit. The trend indicated in these figures is that the attenuation coefficient increases with increasing frequency, i.e. that the slope becomes progressively more negative. Since attenuation is a property of the medium and not of the measuring system, the data of Figures I to 3 were combined, weighting the slopes at each frequency according to the number of points used to establish the slopes. The results are plotted as points in Figure 4 for attenuation coefficient $\left(\mathrm{db} \mathrm{m}^{-1}\right)$ against frequency $(\mathrm{kHz})$. It is seen that attenuation is an ever rapidly increasing function of frequency. The attenuation coefficient increases from a value of less than $\mathrm{I} \mathrm{db} \mathrm{m} \mathrm{m}^{-1}$ at $10 \mathrm{kHz}$, to about $5 \mathrm{db} \mathrm{m}^{-1}$ at I $00 \mathrm{kHz}$ and to more than $35 \mathrm{db} \mathrm{m}^{-1}$ at $500 \mathrm{kHz}$. As comparison, Westphal (1965) obtained a value for the attenuation coefficient of $0.2 \mathrm{I} 5$ nepers $\mathrm{m}^{-1}\left(\mathrm{I} .9 \mathrm{db} \mathrm{m}^{-1}\right)$ at $\mathrm{I} 5 \mathrm{kHz}$ in glacier ice.

A considerable body of evidence exists (e.g. Mason, I964, p. I63) to indicate that in polycrystalline materials the attenuation may vary as the sum of two frequency-dependent terms. One involves a linear dependency on frequency and is caused by frictional loss mechanisms between grains. The other is a term in the fourth power of the frequency and arises from scattering at the grain boundaries caused by discontinuities in the elastic constants in going from one crystal to the adjacent one. The data of Figure 4 were accordingly fitted, using the least-squares method, by an equation of the form

$$
\alpha=c_{1} f+c_{2} f^{4}
$$

where $\alpha$ is the attenuation coefficient, $f$ is the frequency, $c_{1}=4.45 \times 10^{-2} \mathrm{db} \mathrm{m}^{-1} \mathrm{kHz}^{-1}$, and $c_{2}=2.18 \times \mathrm{IO}^{-10} \mathrm{db} \mathrm{m}^{-1} \mathrm{kHz}^{-4}$.

It is seen that the curve fits the data points reasonably well. The points seem to follow a series of oscillations above the curve which may be caused by thermal relaxation processes. However no attempt was made to investigate these features.

\section{Discussion}

Calculations indicate that the linear term in the above equation is the predominant one in the frequency band studied. It accounts for more than $99.9 \%$ of the attenuation at frequencies below $60 \mathrm{kHz}$, for $99 \%$ at about $120 \mathrm{kHz}$, for $90 \%$ at somewhat less than $300 \mathrm{kHz}$ and for $60 \%$ at about $500 \mathrm{kHz}$. This result is not entirely unexpected when one considers that sea ice has a complicated substructure of platelets with heavy concentration of liquid brine in cells between the platelets and also numerous air bubbles. The brine cells, air bubbles, platelets and even grains may act as sites of strain concentration resulting from passage of the acoustic pressure wave. Savage ( $\left.\mathrm{I}_{9} 6_{5}\right)$ points out that localized temperature fluctuations would be induced at such sites and that the diffusion of these fluctuations by conduction produces the loss mechanism which he calls thermoelastic internal friction.

As for the scattering term, since the velocity of compressional waves in sea ice of the properties encountered is about $3.7 \times 10^{3} \mathrm{~m} \mathrm{~s}^{-1}$ (Langleben, 1962), the wavelength of the acoustic waves approaches the typical horizontal dimension of the ice crystals, about $2 \mathrm{~cm}$, at a frequency of approximately $130 \mathrm{kHz}$. It would thus appear that, in a lossy medium such as sea ice, Rayleigh-type scattering is insignificant compared with other loss mechanisms until frequencies having wavelengths very much less than the average crystal size are attained.

\section{Acknowledgements}

This work has been supported by the U.S. Naval Ordnance Laboratory under ONR Contract NONR 49i5(oo), Task No. NR 307-29o and by the Defence Research Board of Canada under D.D.P. Contract GR.8r 3007 . Dr G. Hattersley-Smith arranged the logistics of the field trip and Mr P. Stalinski assisted with the measurements.

MS. received 25 January 1969 


\section{REFERENCES}

Anderson, D. L. 1958. Preliminary results and review of sea ice elasticity and related studies. Transactions of the Engineering Institute of Canada, Vol. 2, No. 3, p. $116-22$.

Knopoff, L., and MacDonald, G. J. F. 1958 . Attenuation of small amplitude stress waves in solids. Reviews of Modern Physics, Vol. 3o, No. 4, p. $1178-92$.

Langleben, M. P. 1962. Young's modulus for sea ice. Canadian Journal of Physics, Vol. 40, No. 1, p. I-8.

Mason, W. P., ed. 1964. Physical acoustics. Principles and methods. Vol. 1, Pt. A. New York, Academic Press.

Mason, W. P., and McSkimin, H. J. 1947. Attenuation and scattering of high frequency sound waves in metals and glasses. Journal of the Acoustical Society of America, Vol. 19, No. 3, p. 464-73.

Pounder, E. R., and Langleben, M. P. 1964 . Arctic sea ice of various ages. II. Elastic properties. Journal of Glaciology, Vol. 5, No. 37, p. 99-105.

Pounder, E. R., and Langleben, M. P. 1968. Acoustic attenuation in sea ice. Union de Géodésie et Géophysique Internationale. Association Internationale d'Hydrologie Scientifique. Assemblée générale de Berne, 25 sept.-7 oct. 1967. [Commission de Neiges et Glaces.] Rapports et discussions, p. 16 1-69.

Savage, J. C. 1965. Attenuation of elastic waves in granular mediums. Journal of Geophysical Research, Vol. 70,

No. 16, p. 3935-42. In situ acoustic attenuation measurements in glacial ice. Fournal of Geophysical Research,
Westphal, J. A. 1965 . In Vol. 70, No. 8, p. 1849-53. 